This is an electronic reprint of the original article. This reprint may differ from the original in pagination and typographic detail.

Author(s): Ojakangas, Mika

Title: Biopolitics in the Political Thought of Classical Greece

Year: $\quad 2017$

Version:

Please cite the original version:

Ojakangas, M. (2017). Biopolitics in the Political Thought of Classical Greece. In S. Prozorov, \& S. Rentea (Eds.), The Routledge Handbook of Biopolitics (pp. 23-35). Routledge. https://doi.org/10.4324/9781315612751-2

All material supplied via JYX is protected by copyright and other intellectual property rights, and duplication or sale of all or part of any of the repository collections is not permitted, except that material may be duplicated by you for your research use or educational purposes in electronic or print form. You must obtain permission for any other use. Electronic or print copies may not be offered, whether for sale or otherwise to anyone who is not an authorised user. 


\section{Biopolitics in the Political Thought of Cassical Greece}

\section{Introduction}

This article deals with biopolitics in classical Greek thought. Its aim is to demonstrate that biopolitics is not a distinctively modern phenomenon. It is as old a phenomenon as western political thought itself. Focusing on Aristotle's Politics as well as Plato's Republic and Laws, I argue that the politico-philosophical categories of classical thought were already biopolitical categories. In their books on politics, Plato and Aristotle do not only deal with all the central topics of biopolitics (sexual intercourse, marriage, pregnancy, childcare, public health, education, population, and so forth) from the political point of view but for them these topics are the very keystone of politics and the art of government. At issue is not only a politics for which 'the idea of governing people' (Foucault 2007, 122) is the leading idea but also a politics for which the question how 'to organize life' (Polit. 307e) is the most important question. This politics is not characterized by what Foucault calls the juridicoinstitutional model of politics revolving around laws, legal subjects, contracts, liberties, obligations, rights, and duties. Platonic and Aristotelian politics concern the technologies of power over the natural life of the 'tame animals' (Leg. 6.766a) called human beings. By focusing primarily on the quantity and the quality of population (Pol. 7.1326a5-7) they aim at controlling and regulating the domain of the living (en tois zôois) (Polit. 261c-d) in order to attain the ultimate aim of politics: the prosperity and happiness of the city-state.

\section{Aristotle's Politics}

Let us start our analysis with Aristotle's Politics for a genealogical reason. Plato's Republic and the Laws were not translated into Latin until the end of $15^{\text {th }}$ century, whereas Aristotle Politics was available in Latin already at the end of the $12^{\text {th }}$ century. Moreover, Aristotle's ideas in Politics were adopted sooner, first by the Scholastics reflecting on politics and later on by the early modern political theorists and experts in police, while Plato's biopolitical ideals, Renaissance utopia literature excluding, were not embraced before the $18^{\text {th }}$ century. What is it that allows us to treat the Politics as a treatise on biopolitics? There are three main reasons for doing so. First, the ultimate telos of politics is to ensure the happiness (eudaimonia) of the city-state (Pol. 71328b30-35) and the felicity (makariôs) of its inhabitants (Pol. 7.1324a23-26). Second, the principal and the most effective means for achieving this end is the regulation of the quality and the quantity of population: 'As to the necessary things for the state to be considered there first comes [proton] the question of population, its quantity and its natural quality [posous te kai poious tinas huparkhein dei phusei]' (Pol. 7.1326a5-7). As an eminent naturalist, third, Aristotle also held that state policies must be adjusted to the immanent processes of nature (phusis). Like any other arts, politics aims at developing nature, at bringing it to fruition - and if necessary, at filling up 'nature's deficiencies' (Pol. 7.1337a1-2), for mistakes are as possible in the operations of nature (phusis) as in the operations of art (tekhne) (Phys. 2.199a33-199b1). Yet one cannot fill up nature's deficiencies if one does not know its principles, be they those of procreation or of psychic life: 'It is clear that the statesman must have some acquaintance with psychology, just as the physician who is to heal the eye or the other parts of the body must know their anatomy' (Nic. Eth. 1.1102a15-25). In other words, the ultimate aim of the art of government is to promote the happiness of the city-state and its inhabitants, the main 
means for achieving this end being the regulation of the quality and the quantity of population according to the immanent norms of life known by the inquiry of human nature. What could be more biopolitical?

Of course, we must take a closer look at what aspects of life Aristotle was thinking of when he stressed the quality and the quantity of population, keeping in mind what Foucault $(1990,25-6)$ said about biopolitics revolving around questions such as the birthrate, the age of marriage, the legitimate and illegitimate births, the precocity and frequency of sexual relations, the effects of unmarried life, and so on. Are these and related issues monitored and regulated in the Aristotelian system of state administration? They are. First of all, says Aristotle, the magistrates must 'pay attention to the union of the sexes' (Pol. 7.1334b31-32), that is to say, when and with whom one should marry and practice matrimonial intercourse. This is essential because by producing children the parents are serving the state (Pol. 1335b28-29), particularly if the natural disposition of the children is suitable for it. To this end, the magistrates must see to it that people do not get married too young, because the offspring of the young are 'more imperfect and likely to produce female children' (Pol. 7.1335a10-15). The best age to be married is eighteen for women and thirty-seven for men 'for that will give long enough for the union to take place with their bodily vigor at its prime' (Pol. 7.1335a27-30). The magistrates must also decide how long it is suitable for a couple to serve the state by producing children, for the offspring of parents who are too old are either weaklings or 'born imperfect both in body and mind' (Pol. 1335b28-32). Finally, the maximum number of offspring must be fixed by the state (Pol. 7.1335b23). These last two rules - the age limit and the number of children - must be implemented by the threat of abortion: 'If any people have a child as a result of intercourse in contravention of these regulations, abortion must be practiced on it' (Pol. 7.1335b23-24). There must also be a rule that 'no deformed child shall be reared' (Pol. 7.1335b19-20).

Furthermore, the magistrates must pay attention to what kind of bodily constitution of the parents is beneficial for the offspring. For instance, the athlete's body is not serviceable for health and parentage, 'nor yet is a habit that is too valetudinarian and unfit for labor' (Pol. 7.1335b5-10). The magistrates are also to see to it that pregnant women take care of their bodies, 'not avoiding exercise nor adopting a low diet,' for 'children before birth are evidently affected by the mother just as growing plants are by the earth' (Pol. 7.1335b1418). The magistrates must also give advice on how the children should be reared 'to obtain the best bodily frames' (Pol. 7.1334b28-31), as children's bodies must be suited to the wishes of the magistrates (Pol. 7.1335a5-6). In this regard, the rules concerning nourishment are essential: 'When the children have been born, the particular food adopted must be deemed an important determining influence in regard to their power of body'(Pol. 7.1336a3-5). The magistrates must also see to it that parents accustom the offspring from early childhood to cold, for 'this is most useful both for health and with a view to military service' (Pol. 7.1336a10-15). Equally important is bodily exercise, but not too much or too laborious as it hinders growth (Pol. 7.1336a20-25). The magistrates should also prescribe what kind of exercises, games, and fairytales are appropriate for children: 'Most children's games should be imitations of the serious occupations of later life' (Pol. 7.1336a34-35). As to the education of children, it is essential, according to Aristotle, that it is public and not private (Pol. 8.1337a22-23). The supervision of education belongs to paidonomous who also control children's pastimes (Pol. 7.1336a30-1336b4). Education itself is divided into three 
age groups in accordance with the children's developmental phases: from two to seven, from seven to puberty, and from puberty to the age of twenty-one. Regarding the content of education, Aristotle first argues that 'education ought to be adapted to the particular form of constitution,' for education is constitutive of one's character (êthos) and it is precisely character on the basis of which constitution is created and preserved (Pol. 7.1337a14-18). He then continues that the young must be taught useful arts that are indispensable, including reading and writing, gymnastics, drawing, and music. Reading and writing are useful for business (khrêmatismos), for household management (oikonomia), for studying, and for learning the practices of political life (politikas praxeis), while drawing is useful in making us better judges of artworks and gymnastics for the sake of health and strength (Pol. 8.1338a15-20).

When it comes to the quantity of population, Aristotle is not, unlike many early modern theorists of police before Physiocrats and Malthus, preoccupied with the mere increase of population, simply because his ideal state is not as populous as possible but one that includes an appropriate number of people, this appropriateness depending on the natural function of the state: 'M ost people ... judge a great state by the numerical magnitude of the population, but really the more proper thing to look at is not numbers but efficiency' (Pol. 7.1326a7-15). On the one hand, it is difficult to govern well a state with a very large population: 'One cannot organize an excessively large number' (Pol. 7.1326a30). A state consisting of too few people is not preferable either (Pol. 7.1326a25-b10). The ideal population size is one where the rulers of the state are able to see the entire population at a glance but still large enough to be self-sufficient for the purpose of living the good life (Pol. 7.1326b20-25). In addition to the total number of inhabitants, the magistrates should consider the balance between socio-economic classes and different subpopulations. The question of balance is essential for the happiness of the state but it also pertains to its security. Regarding the latter, the balance between the rich and the poor is the most important, for in Aristotle's estimation too big a difference in this respect is the main cause of upheaval (stasis) in the state (Pol. 5.1301b26). One way of reducing the inequality between these classes is to improve the condition of the poor, though charity is out of the question (Pol. 6.1320a32). A more effective means is to offer them start-up capital (Pol. 6.1320a35-40). However, Aristotle does not believe that the gap between the rich and the poor can be entirely abolished, but this is not even desirable (Pol. 2.1267a38-39), for if the difference is totally erased, the very existence of the constitution is at peril. It is at peril because a state without rich people is unable to supply the magistrates, military, common tables, and religious rituals, which all are necessary for good government (Pol. 5.1310a1). The point is rather to keep the number of the poor within acceptable limits, as revolts are very likely to occur if the number of the poor increases too much in the state (Pol. 5.13032a35-45). The problem is even more urgent if the rich become pauperized - not only because they supply the state institutions but also because it is the impoverished rich that most likely 'endeavor revolutionary action' (Pol. 2.1266b14-15). Thus, more essential than to reduce the number of the poor in the state is to keep the rich satisfied (Pol. 2.1267b4041 ), though the best solution is to increase the middle class (Pol. 4.1295b35-40).

In addition to the quality and the quantity of the population as well as the division of power and wealth among subpopulations, statesmen must pay attention to the territory (khôra) of the state (Pol. 2.1265a20-21). Like the question of population, the question of territory 
concerns its 'size [posos] and quality [poios]' (Pol. 7.1326a8). In this regard, the statesman must focus on three aspects: fertility, security, and health. The territory must be such that there is a plentiful natural supply of water (Pol. 7.1330b10-15). It should also be fertile enough to provide a sufficient amount of food and other necessary products (Pol. 7.1326b25-30). Yet no state is so self-sufficient that it can do without exchange of products with other countries, which means that the location should also be favorable for import and export. To this end, it is desirable that the state has access to the sea - even if this brings about unwanted consequences, such as excessive immigration and migration of merchants (Pol. 7.1327a8-20). It is advantageous for military defense as well. In order to wage war successfully, it is strategically useful if the state can attack the enemy both from the land and the sea (Pol. 7.1327a20-24). Furthermore, the entire territory should be clearly observable, as this prevents the enemy from intruding into the country in secret (Pol. 7.1327a5), but it should also be difficult for the enemy to approach and blockade (Pol. 7.1330b1-2). In addition, the statesman should pay attention to the site of the city with regard to 'the health of the inhabitants' (Pol. 7.1330b7). A preferable site is one that slopes east or towards the breezes that blow from the sunrise, because in such cities the population is usually healthier (Pol. 7.1330a38-40).

Besides population and territory, Aristotle maintains, magistrates must pay heed to the economic affairs in the state. How wealthy should the state be? How should this wealth be obtained and distributed? Should it be private or public and if both, to what extent should it be public? The first question indicates that the best state is not necessarily the wealthiest state. To the same extent that there is a proper limit to the number of people in the state, there is also a proper limit to wealth. In this regard, Aristotle's reasoning differs from the modern state rationality. Since the birth of this rationality, one of its most integral elements has been, according to Foucault (2001a; 2007), the continuous increase of wealth. In Aristotle's estimation, the wealthiest state is not necessarily secure and happy. Although Aristotle asserts (Pol. 6.1320a35) that the state must contrive measures that 'may bring about lasting prosperity,' he also believes that there is a proper limit to wealth. Obviously, a state cannot be happy if it is too poor (Pol. 1328b5-15). It is also likely that such a state is unable to defend itself against enemies, as a poor country cannot afford to maintain a military force efficient enough to deter potential assailants (Pol. 1331a12-18). However, excessive wealth is not desirable either, for it will be coveted by stronger neighboring states (Pol. 2.1267a20-25). The optimal upper limit for wealth would be one which still does not tempt a stronger foreign state to wage war solely for economic gain (Pol. 2.1267a28-32). When it comes to the division of property, Aristotle maintains that for the main part property should be private, for people have a propensity to neglect common property as much as they are keen on taking care of their own (Pol. 2.1263a25-30). This is not to say that he leaves private property without state regulation, for he opines that the amount of property each household may possess must be fixed by law (Pol. 2.1266b10-11). Aristotle does not say explicitly what the proper limit of property is but he recommends that the state see to it that nobody become excessively rich (Pol. 5.1308b15-20).

It is sometimes argued that the ancient Greek society was characterized by a strict separation of the polis and the oikos, the public and the private sphere. In this regard, Hannah Arendt's interpretation is a case in point. In her view, the politics of the polis did not concern things necessary to sustenance of life related to bodily needs. Things such as birth, 
death, procreation, health, sickness, longevity, even economy, were strictly excluded from politics and restricted to the sphere of the oikos (Arendt 1958, 38-48). Yet, given the fact that even the most private aspects of affairs allegedly belonging to the sphere of the oikos are under the strict control of political authorities in the Politics, including sexual behavior, the number of children, child rearing, and private property, it seems clear that Aristotle does not recognize such a strict division between the oikos and the polis. Indeed, Aristotle himself explicitly proclaims that the oikos and the polis are not separate spheres but 'constitute a unit' (Pol. 2.1263b30-31) and more precisely, a unit in which the polis is the determining entity, as citizens do not belong to themselves, but 'all belong to the state' (Pol. 8.1337a27-28). Although Aristotle admits that some things are one's own (idia) and some held in common (koina), this does not entail that in his view there is an autonomous private sphere in the polis in whose matters the magistrates have no authority to intervene. Seeing to the security and happiness of the state, it is, in Aristotle's view, up to the magistrates to decide what is one's own and what is common.

Besides, if state intervention into the private sphere would have been a delicate issue for Aristotle to deal with in the context of classical Greece, he would arguably have needed to legitimize it. Yet we cannot find even a hint of possible legitimacy problems in the Politics. The reason is obvious: Aristotle's attitude reflects the general Greek pattern of thought and practice. The Greek oikos was not beyond the reach of political regulation because the Greek city-state was not a modern liberal space constituted by different autonomous spheres such as the private, cultural, economic, or religious sphere. The Greek city-state was, to use Carl Schmitt's $(1999,22)$ formulation, a total state - a state that intervenes, if it so wishes, 'in all possible matters, in economy and in all the other spheres of human existence.' In the total state, there is no distinction between the state and society and the same holds for the Greek polis: 'The interpenetration of economic, political, social, moral, and religious aspects of life - of public and private realms - was much more intense and complete in a polis than in any other form of state, ancient or modern' (Nagle 2006, 10; see also Mulgan 1990). In point of fact, politics itself was household management (oikonomia) writ large in the Greek city-state. The city-state is governed both 'by its nomoi and by oikonomia,' as Aristotle says in the Politics $(5.1308 \mathrm{~b} 30)$, for the magistrates do not only judge lawsuits but also manage the affairs of the state (Pol. 7.1326b15). In Greek literature, moreover, the most commonly used verb denoting this management is oikeô (present infinitive oikeisthai), meaning 'to manage house'. ${ }^{1}$ Not only do Thucydides, Euripides, Isocrates, Aeschines, and Plato repeatedly employ the verb to indicate the management of the city-state as a whole but the same usage can frequently be found also in Aristotle's Politics (see e.g. 2.1261a1-4, 3.1283a17-25, 3.1283b10-13, 4.1298b12-13, 6.1321b5-10, 7.1325a1-2, 7.1331b5-10). In his assessment, the happiness of the state depends entirely on whether it is well administered (kalôs oikêisthai) (Pol. 3.1284b38-42).

Plato's Republic

Let us now take a look at Plato's Republic and the biopolitical measures in the ideal citystate Plato calls Kallipolis, starting with the aim of government. This is again the happiness

\footnotetext{
${ }^{1}$ Thus it was not only with the Hellenistic age, as Giorgio Agamben $(2011,24)$ maintains, that the political and economic vocabularies entered 'a relation of mutual contamination.' These vocabularies were 'mutually contaminated' at the very beginning of western political thought.
} 
(eudaimônia) of the city-state and its inhabitants (Rep. 4.420d). In the Republic, the inseparability of the polis and the oikos is also obvious, even more obvious than for Aristotle, for at least among the guardian class it is absolute, as they have nothing of their own, not even their children belong to them. What about the political regulation of the population? In the Politics (2.1265a37-38), Aristotle accuses Plato of leaving the quantity of population unregulated in Kallipolis, but his account is only partially true. Plato does not provide an exact number of inhabitants but he does hold that their number must be controlled and fixed. Yet the exact number of inhabitants cannot be fixed in advance by legislation, for many uncontrollable factors, such as wars and epidemics, influence the number of people. Therefore, it must be left to the discretion of the rulers to see to it that the city 'may not grow too great or too small' (Rep. 5.460a). Yet Aristotle is also right in the sense that much more attention in the Republic is paid to the regulation of the quality than the quantity of population.

Just like Aristotle later on, Plato argues that political and administrative control of sexual conduct of the inhabitants is absolutely indispensable in a state that purports to be happy. In this regard, the leaders of the state should not suffer the 'slightest disorder' (Rep. 5.458e). The point of departure in Plato's reflection is the whole population. According to Plato, it must first be divided into three separate races (genê): manual laborers, meaning farmers and artisans, and guardians, meaning auxiliaries (epikourous) (arkhontes). This classification must be based on the inborn physical and mental qualities (phuseis) of individuals. Furthermore, to the extent that in Plato's view physical and mental qualities are mainly inherited (Rep. 3.425a), ${ }^{2}$ these classes must be exclusive. A farmer cannot become a guardian during his lifetime and it is also strictly forbidden for him to have sexual intercourse with the members of the superior race - and vice versa. In order to ensure that such an organization of population takes place and becomes effective, the leaders of the state must resort to a story of different metals (iron, silver, and gold) that God has put in the souls of individuals (Rep. 3.425a). Thus if one is born as a son of a farmer, for instance, he must accept that God has mixed iron in his psychosomatic disposition and that he has by this act been assigned to manual labor. On the other hand, Plato admits that the metals in the soul of the offspring do not always correspond to the metals of their parents. Therefore, it is the 'first and most important command from the god to the rulers' (Rep. $3.415 \mathrm{~b}$ ) that the leaders in charge of the city watch carefully the mixture of metals in the souls of the next generation - the mixture that determines one's position in the city-state. Hence, if some parents from the inferior races happen to produce children 'sound of limb and mind' (Rep. 7.536b), they are qualified to become guardians (Rep. 4.423c). Correspondingly, if bad offspring is born to guardians, it must be sent away to live among the inferior races (Rep. 4.423d). It is not one's social class that determines one's position in the city-state but one's inborn features that determine one's race: those who are euphueis (good by nature) are also leaders by nature, while those that are kakophueis (bad by nature) are followers and subjects. 'Nature binds some ... to be the leaders of the state, some to follow their leaders' (Rep. $5.474 \mathrm{~b}-\mathrm{c}$ ). One cannot become a guardian if one is not a guardian by nature (kata phusin) (Rep. 6.489e), superior in terms of his or her bodily vigor, military strength, mental health, memory, and intellect.

\footnotetext{
${ }^{2}$ It is 'according to nature' (kata phusin) for good men to have good sons, as Plato says also in Cratylus (393c94a). The idea that like parents produce like children is consistent with Plato's philosophical 'like-from-like' principle. See Gorgias 510b and Phaedrus 240c.
} 
After the fourth book of the Republic, the focus of Plato's reflection is exclusively on the guardian race, particularly on the question how to ensure that this race 'remains pure' (katharon esesthai) (Rep. 5.459a-460c). This is understandable, for the happiness of the Platonic state depends primarily on the racial purity of its leaders: 'They alone are decisive of its good government and happiness' (Rep. 4.421a). It is precisely the preservation of this purity that requires an absolute control of sexuality. The first rule is that there must be no other marriages or rather, sexual acts, than those approved by the leaders of the state (Rep. 5.447d and 458d), as 'marriages' between couples do not last longer than the festivals where the couples are brought together by the leaders (Rep. 5.459e). The point of this control is to ensure that only the best individuals have sex - as frequently as possible: 'The best men must have sex with the best women as frequently as possible, while the opposite is true of the worst men and worst women' (Rep. 5.459d). In order to ensure that those who are not qualified to have sex do not blame the leaders but their bad luck, a fake ballot that supposedly determines people's unions must be organized (Rep. 5.460a). If it nonetheless happens that the inferior individuals do have sex without a license and produce a child, the child must be counted as a product of 'darkness and lasciviousness' (Rep. 5.461b-c) who should not be nurtured: 'If our herd [poimnion] is to be of the highest possible quality, the former's [superior individuals] offspring must be reared but not the latter's [inferior individuals]' (Rep. 5.459e). These latter children, as well as any child that is born defective, even if it is born to superior individuals, must be deported to 'some secret and unknown place' and exposed to death (Rep. 5.460c).

All these measures are absolutely crucial because the state cannot be happy if its leaders are not racially pure, for racial impurity, the mixing of good and bad types, is an 'unharmonious abnormality (anômalia anarmostos)' and the primary cause of the degeneration (metabasis) of the state (Rep. 7.546e-547a). How can the leaders of the state ensure that it is precisely the best individuals who reproduce? It is this question that evokes Plato to suggest sexual 'communism.' The first condition of possibility for a racially vigorous class of guardians to emerge is the abolition of traditional marriage. In the traditional Greek marriage, the head of the household had the authority to decide whom his child married (Lacey 1969), but in Plato's estimation the problem with such an arrangement is that the father hardly pays attention to the natural qualities of the spouses, focusing on the kinship relations alone. Furthermore, even if he did, monogamous and lifelong marriage prevents the most vigorous men from having sex with the best women 'as frequently as possible,' which is necessary if the individuals with a good natural disposition are to produce more children than others. This remains the case even if the best men are married with the best women, for traditional customs prohibit adultery, which means that even the most vigorous men cannot have children with any other women than their wives. Finally, the traditional marriage is a lifelong arrangement, but people do not preserve their sexual vitality throughout their lives. For these reasons marriages in Plato's state are momentary, lasting no longer than the festivals where the couples are brought together.

The abolition of the traditional marriage is not a sufficient condition of producing sound offspring. The leaders must also see to it that it is precisely the 'strongest, bravest and most beautiful' (Rep. 7.535a) that do have sex as frequently as possible. One way to approach this goal is to reward courage in war with 'the opportunity of more frequent intercourse,' as this 
is a 'plausible pretext for having them beget as many of the children as possible' (Rep. $5.460 \mathrm{~b})$. The problem is that success in warfare does not exclude the possibility of low intellectual capacity. In this regard, a more reliable method is to remove the children from their parents' tutelage immediately after birth, to the effect that they are first taken to public nurseries (Rep. 5.460c-d) and then to camps in the countryside where they are observed and supervised by the guardians (Rep. 7.540e-541a). It is here that the guardians can best discern the inborn and natural qualities of each child individually, particularly because the children are assigned to go through a series of tests (Rep. 3.413d). Only those who endure these tests and issue from them unspoiled - tests in which children are exposed both to extreme fears and extreme pleasures (Rep. 3.414a) - can have sex and procreate.

There are two guiding principles in the Platonic population policies in the Republic. One is selective animal breeding. In Plato's view, the same principles that are applied in the breeding of domestic animals aiming at the production of thoroughbreds must be applied to men: only the pedigrees are allowed to breed. Even the famous equality of the sexes (Rep. $5.451 d-e)$ is legitimized on these grounds. As little as you pay attention to the sex of a watchdog when you choose the best, as little you should pay attention to it when you select the best rulers for the state. It is not sex but the health and the strength of the disposition that matters. Another guiding principle is the medical art. Yet the difference is not that big, as in both arts, in Plato's view, you have to take drastic measures in order to achieve lasting results - namely the amputation of the weak elements from the body, be it individual or collective. In this regard, it is not Hippocrates but Asclepius that must be imitated, for unlike Hippocrates, Asclepius, the very god of medicine, knew that there are lives not worth living and therefore, not worth medical treatment (Rep. 3.407d-e). In Plato's estimation, a life is not worth living if one's body is unhealthy or if one's soul is incurably evil. With regard to such men, Plato's advice is as follows:

These arts [medicine and jurisprudence] will care for the bodies and souls of such of your citizens as are truly well born [euphueis], but of those who are not, such as are defective in body they will suffer to die and those who are illnatured and incurable in soul [kata tên psukhên kakophueis kai aniatous] they will themselves put to death. (Rep. 3.410a)

In The Abnormal (2003a, 298-9), Foucault points out that medicine and psychiatry, at a given historical junction, ceased to have a primarily therapeutic function and, instead, served to maintain and protect society from contact with the abnormal. In Foucault's account this historical development takes place during the 19th century, but given the evidence above, it seems that medicine has embraced that prophylactic function from the very beginning - at least if we are to believe Plato's testimony. At any rate, it was this function Plato assigned to medicine in his political philosophy - and it was in this medical function that political philosophy itself, born in the philosophy of Plato, found its proper task. In this philosophy, constitutive of the western understanding of politics, there is no difference between a judge and a doctor, for judges have become doctors and doctors have become judges - and they both have become breeders of the human stock: 'Plato interprets medicine as a form of politics,' says Karl Popper $(2005,147)$, but at the same time Plato understands politics as a 
form of medicine, namely Asclepian medicine that leaves the bodily defective to die and kills those who are endowed with a bad natural disposition of the soul. ${ }^{3}$

Plato's Laws

With regard to disciplinary and biopolitical technologies, it is Plato's Laws that stands out most conspicuously. In the Laws (4.710b), Plato maintains again that the task is to find out what kind of a constitution is needed 'for the happiest kind of life,' but here we also encounter a state that aims at the total control of the entire population. In this state, called Magnesia, 'nothing, so far as possible, shall be left uncontrolled' (Leg. 6.760a). It is also vital that 'no one, man or woman, must ever be left without someone in charge of him' and that obedience to the authorities is unconditional 'even in tiny details' (Leg. 12.942a-b). To this end, Magnesia is endowed with 'an unbroken chain' of officials (Leg. 6.758a) whose task is to control, organize, and put to work the inhabitants of the city. There are officials who maintain order in the city and in the countryside, officials in charge of the construction, maintenance, and usage of roads, houses, public buildings, harbors, rivers, and wells, as well as the supply of water and food (Leg. 6.758e-759a), officials who superintend skills and professions (Leg. 8.847a), officials who supervise movement across borders, not only immigration but also the import and export of products, officials who see to it that the city space and property are properly distributed (Leg. 5.744d), and so forth.

The most important officials, however, are those who control and regulate the quantity and the quality of population. They are the very leaders of the state, called the guardians of the laws. They keep 'constant watch over children and adults and people of every age' (Leg. $12.959 \mathrm{~d}-\mathrm{e}$ ), observing 'their pains, pleasures and desires' (Leg. 1.631e-632a). They supervise marriages in particular, making certain that they are beneficial for the state (Leg. 6.773b). By criminalizing celibacy, they also ensure that every adult actually marries (Leg. 6.774a). They supervise sexual behavior in marriage, seeing particularly to it that every couple has children - though the direct control of this belongs to the 'female officials' who must 'enter the homes of the young people' and, by admonitions and threats, coax them to 'give up their ignorant and sinful ways. ${ }^{\prime 4}$ If this has no effect, they must report the case to the guardians, who must resort to sterner methods. (Leg. 6.784c) If a couple has not been able to provide the state with children after ten years of marriage, they must divorce (Leg. 6.784b). The guardians of the laws also control extramarital sexual behavior, particularly nonreproductive sex (homosexuality, masturbation, and prostitution), which is forbidden, together with adultery, by a law which permits 'the sexual act only for its natural purpose, procreation' (Leg. 8.838e-839a).

Although these measures are aimed at increasing population, Plato's stance in the Laws resembles that of Aristotle: the state is not strong simply because of the number of its people. There are populous states that are weak, but a small population is not an advantage either. The proper number of people depends on the size of the domain of the state, the

\footnotetext{
${ }^{3}$ Politics and ethics are either identified with or related to the art of medicine in various Platonic dialogues. In addition to the Republic, see Timaeus (42b), Charmides (171d-e), Phaedrus (270b), Gorgias (464c, 480a-b), Alcibiades I (146e), and the Laws (4.661a, 5.735d). On the medical 'metaphors' in Plato, see also Lidz (1995).

${ }^{4}$ It is very likely that Plato refers here to contraception and abortion. On contraception in classical Greece, see Riddle (1994).
} 
quality of its soil, and the neighboring states - and once these are known, the proper number of people can be fixed (Leg. 5.737c-d). It is essential to control sexuality in order to keep this number unchanged, but more important than the quantity is again the quality of population. According to Plato, the guardians can influence this by working on the environment and the heredity of individuals. First, they must examine the different districts in the state, as some districts are naturally superior to others for the breeding of men of a good type (Leg. 5.747d-e). Thus, they must choose carefully where people should live but even more carefully manage how they live. In this regard, the principal method is education. Because children 'belong to the state first and their parents second,' education is public and compulsory for everybody in Magnesia (Leg. 7.804d). It begins at the age of three, but although the state does not regulate the rearing of children by law before that age, it supervises parents and gives them directives. This supervision begins at pregnancy (Leg. 7.790), for it is essential that expecting women do not experience excessive affections, as these have a negative effect on the embryo (Leg. 7.792e). Generally speaking, upbringing must be based on the channeling of natural desires by inflicting pleasure or pain (Leg. 1.636d-e). Between the ages of three and six when all children are congregated in public kindergartens (Leg. 7.794a) this channeling takes place through play, particularly 'towards the activities in which they will have to engage when they are adult' (Leg. 1.643c-d). From six onwards, children are handed over to the teachers of music, dancing, and gymnastics. While the teachers of music take care of the education of the soul, the teachers of dancing and gymnastics see to it that the children engage in physical exercise, such as running and boxing, as this makes them capable of warfare. To this end, there must also be physical exercises of a military kind (Leg. 7.813d-e). Finally, the children have to learn to read, write, and count: these are necessary skills for the purposes of war, household (oikonomia) and state administration (dioikêsis) (Leg. 7.809c).

Also adults need education, but instead of pedagogues their teachers are the guardians of the laws and the laws themselves, as a good lawgiver (the guardians of the laws are also lawgivers in Magnesia) 'educates the citizens rather than legislates' (Leg. 9.857e). The function of the law is no so much to demarcate the line between licit and illicit but to nurture and educate the living soul (trophên te zôsês pshukhês kai paideian) (Leg. 9.874d). However, to the extent that there cannot be a law for every detail of life, Plato suggests that the leaders should also prescribe social norms of sorts falling between advice and law (Leg. 822d-e). Transgression of these norms does not incur a penalty but the citizens should observe them as if they were laws, for the perfect citizen abides by 'these decisions no less than by the rules enforced by legal penalties' (Leg. 7.823a). Even penalties have an educational function in Magnesia, as sanctions are enforced in order to cure the soul of the criminal (Leg. 11.934a-b). To this end, there are also different types of correctional institutions (Leg. 10.908a-909c) in the city, including one called the sophronistêrion where individuals whose impiety is due to ignorance are sent. The inmates of this institution are isolated from everybody else but the members of the mysterious Nocturnal Council, which consists of the ten eldest guardians of the laws and ninety other citizens (Leg. 12.961a) and enjoys the highest authority in the state (Leg. 12.960b-e). The inmates of the sophronistêrion meet regularly the members of this Council whose task is to restore 'the well-being of their souls' (tês psukhês sôtêria). Once the treatment is over (after five years), an inmate who appears to enjoy good mental health (sôphroneô), should go and live with 
sensible people, but 'if appearances turn out to have been deceptive, and he is reconvicted on a similar charge, he should be punished by death' (Leg. 10.908e-909b). ${ }^{5}$

The idea of sophronisterion is not only fully consistent with Plato's penology but perfectly reflects his eminently biopolitical conceptions of 'evil' (kakos) and 'injustice' (adikia). In the regime of the biopolitical, as Foucault (1995; 2001b; 2003a) has pointed out, 'evil' does not pertain to an act but to a potentiality, that is, to the character of man. An 'evil' person is not a lawbreaker but a dangerous individual in need of education and therapy. Plato would agree. For him, 'evil' and 'injustice' are not attributes of an act but states of the soul. A state of the soul, moreover, can be evil or unjust irrespective of whether the individual endowed with such a soul has caused 'any injury or not' (Leg. 9.863e). Thus, an individual is not evil because he has been found guilty of an offence, as it is well possible that he has never done anything contrary to the laws or customs of the polis, but because there are such 'acquired and natural habits' (Rep. 10.618d) in his soul that render him evil and unjust. Usually, however, Plato does not call them habits but diseases of the soul (psukhês nosos) (Gorg. 480a-b; Rep. 3.408b, 4.444d-e, 10.610a-611a; Leg. 9.853d, 9.854b-c, 9.862c). For Plato, justice is identified with psychic health and injustice with psychic disease. Therefore, it is not surprising that in Plato's view, instead of punishments, vicious individuals, if they appear to be curable (Leg. 8.862c; Gorg. 525b-c), must be provided with 'the remedial treatment of body and mind' (tôn sômatôn kai dianoêseôn therapeias) (Tim. 87c). For Plato, as already said in the previous chapter, politics itself is basically nothing but an art of healing (therapeuô) the souls of men (Leg. 1.650b; Polit. 276b-c), jurisdiction being the art of healing the sick soul, while legislation is what promotes its health (Gorg. 464b). ${ }^{6}$

According to Plato, education or therapeutic institutions do not suffice in making a state happy. It is hard and even impossible to educate everyone, not to mention to heal all those suffering from the mental illness of immorality (Leg. 9.862e). In Magnesia, this difficulty is partially solved by regulating marriages. Although the leaders of Magnesia do not decide with whom people are allowed to marry, they must persuade men to choose a right kind of wife - with whom they can produce children beneficial to the state (Leg. 6.773b). They must also give advice on when and in which condition a couple should have sex. For instance, children should not be conceived when parents are drunk, as drunkards produce children 'unstable both bodily and mentally' (Leg. 6.775d). The same rule applies to all vices, for vicious fathers 'produce absolutely degenerate creatures who have been stamped with the likeness of their father' (Leg. 6.773d-e). If it nonetheless happens that 'degenerate creatures' are born, the officials have to resort to racial selection like 'a shepherd [poimên] or cattle-man [boukolos] or breeder of horses [tropheus te hippôn],' separating the fit from the unfit and expelling the unfit from the city:

Anyone who takes charge of a herd of animals will never get down to looking after them without first performing the purge appropriate to his particular animal-community: that is, he will separate the unhealthy from the healthy and the thoroughbreds [gennaios] from the ill-bred [agennês] sending the illbred off to other herds, while keeping only the thoroughbreds and the healthy animals to look after (Leg. 5.735b).

\footnotetext{
${ }^{5}$ On the discussion on sophronistêrion, see Klosko (1988).

${ }^{6}$ On Plato's penology and vice as a psychic disease, see also Ahonen (2014); M oore (2012); Saunders (1991).
} 
The shepherd must perform such a thorough purge (diakathairô), for he knows that 'unless he purges the existing stock these faults will spread in any herd to the animals that are still physically and temperamentally healthy and unspoiled' (Leg. 5.735c). In other words, illbred and defiled animals are a burden to the whole stock, not only because they are weak but above all because the healthy and undefiled are contaminated by the faults of the weak through interbreeding. In the case of 'other animals,' however, such a purge is 'a matter of minor importance' (Leg. 5.735c). With human beings, it is 'vitally important' (Leg. 5.735c). Among men, the rulers of the state may use either mild or drastic measures, depending on the form of government. A tyrant may use harsh methods and carry out a 'state purge' (katharmous poleôs) drastically, 'which is the best way,' for 'like drastic medicines, the best purge is a painful business' (Leg. $5.735 \mathrm{~d}$ ). It takes the punishment to the point of exile or death.

In the non-tyrannical states, the purge must be milder because people do not necessary accept tyrannical methods. However, if the leaders of a non-tyrannical state are clever enough, they can achieve the same results as tyrants. Although people do not normally accept harsh methods, they may accept them at a moment of crisis, especially if the leaders of the state are able to convince them that the unhealthy and the ill-bred are the cause of the crisis. The same method can be applied, particularly if they are rebellious, to the poor who 'are to be regarded as a disease that has developed in the body politic - and in the friendliest possible way they should be, as it will tactfully be put, transferred to a colony' (Leg. 5.736a). In other words, not only the physically and mentally inferior individuals, but even the poor should be seen as a disease to be eliminated one way or another, even by killing - not because they would have transgressed any laws of the city but because their inherent weakness is contagious: without a thorough purge the rest of the population is in danger of degeneration as well. It is the health and happiness of the rest that legitimates and necessitates the elimination of the weak, irrespective of whether the latter have done something illegal, immoral, or impious: it suffices that they are degenerate by nature and ruined by incompetent breeding. This is racism but it is not traditional Greek anti-barbarism, for it is not the barbarians but those who are inferior by nature (kakophuseis) that must be excluded from the state. Plato's racism in the Republic and the Laws is an entirely new kind of racism. It is what Foucault (2003b) calls biopolitical 'state racism' - racism that society directs against its own elements that threaten the health and purity of its population.

\section{Conclusion}

Plato and Aristotle, as I have hopefully been able to show, understood politics as biopolitics, that is to say, as a practice which aims at controlling and regulating the living, manipulating the natural quality of individual bodies and the quantity of entire populations - so that the city-state and its inhabitants might enjoy happiness. But does this entail that in general, the Greek understanding of politics was also biopolitical in essence? This question is beyond the scope of this article, but it must be taken into account that Plato's and Aristotle's ideas did not develop in a historical vacuum. They represent something deeply rooted in the political sensibility of classical Greece - and here I am not referring only to Spartan state eugenics but also to the Athenian experience of the political, as Aristotle's political science is assuredly a sincere account of this experience. It was not Aristotle's invention to posit the 
question of population as the first question of government. Neither was it his invention to concentrate, in the only treatise he ever wrote exclusively about politics, on the issues that allegedly belong to the sphere of the oikos, such as marriage, childbearing, and childrearing. Although some of Plato's ideas might have been extraordinary in the Athenian context, particularly the biopolitical equality of the sexes, it is quite generally agreed that none of Aristotle's political ideas were very original. However, it is not only Plato's political thought, laden by state racist arguments, but also - and to some extent precisely - Aristotle's political science that is eminently biopolitical.

Although I have argued that the western understanding of politics was already essentially biopolitical in ancient Greece, this is not to say that the history of biopolitics would constitute a continuum from antiquity to the $20^{\text {th }}$ century. This history is marked by several ruptures understood as obstacles preventing the diffusion of the Platonic-Aristotelian biopolitical model of politics - despite the influence these philosophers otherwise had on the Roman and Christian thought. Among these ruptures, we may include: 1) the legalization of politics and the political subject in the Roman Republic, 2) the privatization of everyday life in the Roman Empire, and 3) the de-regularization of biological life in the Christian Empire. Hence, the decline of the Greek city-state also entailed the decline of the biopolitical vision. It was not until the renaissance of the classical culture and literature including the translation of Aristotle's and Plato's political works - that the biopolitical vision originating in Greek political thought became topical gain. It is not the Christian pastorate, but the governmental wisdom of the Greek world that is the point of the shift of the modern political rationality from police to biopolitics, from the early modern art of governing men to the modern eugenic regulation of populations.

\section{Abbreviations}

Plato

Gorg. $=$ Gorgias

Leg. = Laws

Polit. =Statesman

Rep. $=$ Republic

\section{Aristotle}

Nic. Eth. = Nicomachean Ethics

Phys. $=$ Physics

Pol. = Politics

\section{Bibliography}

Agamben, G., 2011. The Kingdom and the Glory. Stanford: Stanford University Press.

Ahonen, M., 2014. M ental Disorders in Ancient Philosophy. Cham: Springer.

Arendt, H., 1958. The Human Condition. Chicago: Chicago University Press. 
Aristotle, 1926-1957. Aristotle in Twenty-Three Volumes, vols. 4, 19, 21. Cambridge, MA: Harvard University Press.

Foucault, M. 2001b. About the Concept of the 'Dangerous Individual' in Nineteenth-century Legal Psychiatry. In: J. D. Faubion, ed. 2001. Power: Essential Works of Foucault 1954-1984, vol. 3. New York: New Press, pp. 176-200.

Foucault, M., 1990. History of Sexuality, Vol. 1: An Introduction. New York: Vintage Books.

Foucault, M., 1995. Discipline and Punish. New York: Vintage Books.

Foucault, M., 2001a. 'Omnes \& Singulatim': Towards a Critique of Political Reason. In: J. D. Faubion, ed. 2001. Power: Essential Works of Foucault 1954-1984, vol. 3. New York: New Press, pp. 298-325.

Foucault, M., 2003a. Abnormal: Lectures at the Collège de France 1974-1975. New York: Picador.

Foucault, M., 2003b. 'Society Must Be Defended': Lectures at the Collège de France 19751976. New York: Picador.

Foucault, M., 2007. Security, Territory, Population: Lectures at the Collège de France. Basingstoke: Palgrave.

Klosko, G., 1988. The Nocturnal Council in Plato's Laws. Political Studies 36(1), pp. 74-88

Lacey, W.K., 1969. The Family in Classical Greece. London, Thames and Hudson.

Lidz, J.W., 1995. Medicine as Metaphor in Plato. The Journal of Medicine and Philosophy 20(5), pp. 527-541.

Moore, K.R. 2012. Plato, Politics and a Practical Utopia: Social Constructivism and Civic Planning in the Laws. New York: Continuum.

Mulgan, R., 1990. Aristotle and the Value of Political Participation. Political Theory, 18(2), pp. $195-215$.

Nagle, D.B., 2006. The Household as the Foundation of Aristotle's Polis. Cambridge: Cambridge University Press.

Plato (1926-1969), Plato in Twelve Volumes, vols. 1, 3, 4-6, 8-12. Cambridge, MA: Harvard University Press.

Popper, K., 2005. Open Society and Its Enemies, vol. 1: The Spell of Plato. London: Routledge.

Riddle, J.M., 1994. Contraception and Abortion from the Ancient World to Renaissance. Cambridge M A: Harvard University Press. 
Saunders, T.J., 1991. Plato's Penal Code: Tradition, Controversy, and Reform in Greek Penology. Oxford: Clarendon Press.

Schmitt, C., 1996. The Concept of the Political. Chicago: Chicago University Press. 